\title{
Environmental Regulations (its Identification and Downstream Implementation in Bangka Belitung)
}

\author{
Dwi Haryadi ${ }^{1, *}$, Ibrahim $^{2}$, and Darwance ${ }^{3}$ \\ ${ }^{1}$ Law Department, Bangka Belitung University, Indonesia \\ ${ }^{2}$ Polotical Science Department, Bangka Belitung University, Indonesia \\ ${ }^{3}$ Law Department, Bangka Belitung University, Indonesia
}

\begin{abstract}
Article $28 \mathrm{H}$ and section (4) of Article 33 in the Indonesian Constitution guarantee every citizen the right to a good and healthy environment with green economy. In order to implement it, the government issued Law No. 32 of 2009 on Environmental Protection and Management. The environmental regulations that became the umbrella act are facing challenges both in substance and implementation. Substantially, questions remain whether the green constitution has been incarnated in this regulation, and how it positions itself as the umbrella act for a number of regulations. In implementation, the challenges include the availability of legislations, from government regulations to technical policy, and its implementation in regional level, both at the provincial and regency levels in Bangka Belitung Islands. In each regime, the environmental issues have always been a part of strategic issues. This research focused on identifying environmental regulations from upstream to downstream, and how they are implemented in the context of environmental issues due to tin mining in Bangka Belitung. Data were obtained through literature review using statute and conceptual approaches.
\end{abstract}

\section{Introduction}

When it comes to environmental regulations in Indonesia, it is interesting to note that it was only in 1982 that the government issued Law No. 4 of 1982 on Principles of Environmental Management as an umbrella act. Previously, the rules concerning the environment were scattered in several regulations. According to Barda Nawawi Arief [1], these regulations include Articles 187, $188,191,202,497,500-503$, and 548-549 of the Criminal Code. In addition, there was Natuurmonumenten Ordonanntie (Natural Monuments Ordinance) Stbl. No. 278 of 1916 which protected flora and fauna. There was also Reeden Reglement of 1925 that prohibited the discharge of litter to harbor and shipping coastlines. This ordinance became invalid since national regulations were issued, such as Law No. 5 of 1990 on Conservation of the Living Natural Resources and Its Ecosystem. Furthermore, there are other environmental regulations in various sectors such as Law No. 5 of 1960 on Basic Agrarian Principles, and Law No. 5 of 1967 on Basic Provisions on Forestry.

The birth of Law No. 4 of 1982 have a constitutional basis in Paragraph IV of the Preamble of 1945 Constitution, which implies the state's obligation to protect the whole people of Indonesia and the entire homeland of Indonesia, including its environment. It is then manifested in Article 33 (3) of Indonesian Constitution. Subsequently, Article III paragraph 10 of MPR (People's Consultative Assembly) Resolution No. IV/MPR/1973 on GBHN (Outlines of State Policy) states that natural resources extraction efforts should not harm human environment. The implementation of this regulation can be extracted from the Presidential Decree No. 11 of 1947. The resolution was then improved with MPR Resolution No. IV/MPR/1978 and Presidential Decree No. 7 of 1979 on Repelita (Five-year Development Plan) Article III Paragraph 7.

Compared to developed countries such as the United States of America, Indonesia has progressed much faster in terms of environmental management. The Indonesian environmental regulation is available in just 37 years after independence as compared to USA's Nation Environmental Policy Act of 1969, which came into force on January 1, 1970, released 200 years after its independence [2].

Indonesia also issued Government Regulation No. 29 of 1986 on Environmental Impact Assessment (AMDAL). Thus, the politics of law on preventing environmental damage through AMDAL has already started since 1980s. In addition, Law No. 4 of 1982 was elaborated with Law No. 23 of 1997 on Environmental Management. In 2009, the regulations were improved with Law No.32 of 2009

* Corresponding author: dwi83belitong@gmail.com 
on Protection and Management of Environment (UU PPLH), as a result of the spirit of regional autonomy, the declining environment quality, the increasing global warming, and the increasing effort to protect the whole ecosystem. Paying attention to the critical environment condition of Bangka Belitung Islands due to tin mining, this study will focus on UU PPLH and its legal order in Bangka Belitung. [3,4].

\section{Methodology}

This normative research takes the form of positive law inventory research on the extent of vertical and horizontal synchronization [5]. Using statute approach and national legislations and regulations, this paper focuses on regional regulations of environmental issues [6]. The data were obtained from primary and secondary legal materials, including national and regional regulations. They were analyzed quantitatively to identify the environmental legal order in Indonesia, and its harmony with regional regulation, especially in Bangka Belitung Islands Province.

\section{Discussion}

\subsection{Green Constitution : Upstream Regulation}

Article 33 (3) and (4) of the 1945 Indonesian Constitution underline that natural resources management is to be controlled by the state and to be exploited to the greatest benefit of the people, and the organization of the national economy shall be based on economic democracy that upholds the principles of solidarity, efficiency, along with fairness, sustainability, keeping the environment in perspective, and self-sufficiency, and that is concerned with balanced progress and the unity of the national economy [7]. Moreover, in terms of human rights, Article $28 \mathrm{H}$ guarantees that each person has a right to a life of well-being in body and mind, to a place to dwell, to enjoy a good and healthy environment, and to receive medical care. Indonesian constitutional law evidently commits to protect human rights and sustainable development in natural resources management. Green constitution is indisputably present in the second and fourth amendment of 1945 Indonesian Constitution.

Article 33, which describes the norms of natural resources management for the benefit of the people, is an interpretation of the fifth principle of Pancasila, the Social Justice for All the People of Indonesia. The founding fathers aspired that the state shall control strategic natural resources to be used to fulfill the government's socio-economic obligation to its people [8].

The 1945 Indonesian Constitution which carries the mandate as a green constitution is the upstream regulation that becomes the main reference for a more concrete and technical regional regulation. Accordingly, the principles of economic democracy in Article 33 of 1945 Indonesian Constitution must be carried out consistently in the construction of natural resources laws. The State-Owned Entrprises (BUMN) regulations in mining and forestry sectors should be focusing on benefitting the people instead of benefitting the capitalists [9].

The implementation of green constitution in Bangka Belitung remains ineffective, as evidenced by the ongoing tin exploitation ever since hundreds of years ago, resulting in environmental damage. Furthermore, restoration efforts through reclamation are inadequate. Consequently, local policy reconstruction is needed $[10$, $11]$.

\subsection{Cross-sectoral Umbrella Act}

UU PPLH is the fundamental regulation or the umbrella act for environmental sectors which include the space, mountains, earth's mantle, to the deep sea. According to Koesnadi, the main principles of environmental management in UU PPLH function as the umbrella act for the construction and adjustment of environmental laws and regulations [12].

The principles in UU PPLH are regulated in Article 2, which comprises state responsibility; conservation and sustainability; harmony and equilibrium; integration; benefit; prudence; justice; eco-region; biological diversity; polluter pays; participation; local wisdom; good governance; and regional autonomy. Environmental laws and regulations have to be constructed based on these principles in order to have substantial integration and to avoid deviation from UU PPLH as the umbrella act.

There are multiple cross-sectoral laws and legislations that concerns the environment, including Law No. 39 of 2014 on Plantations, Law No. 37 of 2014 on Soil and Water Conservation, Law No. 32 of 2014 on Maritime, Law No. 18 of 2013 on Prevention and Eradication of Forest Destruction, Law No. 3 of 2014 on Industrial Affairs, Law No. 11 of 2010 on Cultural Conservation, Law No. 45 of 2009 amending Law No. 31 of 2004 on Fishery, Law No. 36 of 2009 on Health, Law No. 3 of 2009 on Mineral and Coal Mining, Law No. 18 of 2008 on Waste Management, and other older existing laws such as Law No. 5 of 1990 on Conservation of The Living Natural Resources and Its Ecosystem.

Currently there are multiple environmentally-related bills (RUU) that are being discussed that exemplify the principles and purpose of UU PPLH. These bills include Genetic Resources Management Bill, Chemical Substance Bill, Natural Resources Management Bill, Sanitation Bill, Solar Energy Utilization Bill and several bills that amended older laws.

\subsection{Downstream Regulations}

Based on Law No. 12 of 2011, UU PPLH is at the third hierarchy of rules under Indonesian Constitution and People's Consultative Council (MPR) Decree. Therefore, UU PPLH is the downstream regulation from 1945 Indonesian Constitution, specifically Article $28 \mathrm{H}$ and Article 33 section (4). The form of green constitution can be observed by looking at the points of considerations (mengingat), in view of (menimbang), principles (Article 2), purpose (Article 3) and scope (Article 3) of UU PPLH. Further downstream regulations are accentuated through 
Government Regulation, Presidential Regulation, and Provincial/Regency/City Regulation. Regional Regulations will be discussed further in the last part of this paper.

There are at least 18 government regulations (PP) and 9 ministerial regulations mandated by UU PPLH to be issued, including:

\begin{tabular}{|c|l|}
\hline No & \multicolumn{1}{|c|}{ Government Regulations Needed } \\
\hline 1 & $\begin{array}{l}\text { National Environmental Protection and Management } \\
\text { Plan (RPPLH) }\end{array}$ \\
\hline 2 & Environmental Inventory \\
\hline 3 & $\begin{array}{l}\text { Procedure to Determine Support Capacity and Carrying } \\
\text { Capability of Environment }\end{array}$ \\
\hline 4 & $\begin{array}{l}\text { Strategic Environmental Assesment (KLHS) } \\
\text { Organizing Procedure }\end{array}$ \\
\hline 5 & Quality Standard of the Environment \\
\hline 6 & Environmental Impact Analysis (AMDAL) \\
\hline 7 & Environmental Permit \\
\hline 8 & Economic Instruments of the Environment \\
\hline 9 & Environmental Risk Analysis \\
\hline 10 & Environmental Pollution Countermeasures \\
\hline 11 & Environmental Function Restoration \\
\hline 12 & Guarantee Funds \\
\hline 13 & $\begin{array}{l}\text { Conservation and reservation of natural resources and } \\
\text { conservation of atmospheric }\end{array}$ \\
\hline 14 & $\begin{array}{l}\text { Management of Waste of Hazardous and Toxic } \\
\text { Materials (B3) }\end{array}$ \\
\hline 15 & $\begin{array}{l}\text { Procedures and Requirements for the Dumping of } \\
\text { Waste of Materials }\end{array}$ \\
\hline 16 & Environmental Supervisor Appointment Procedure \\
\hline 17 & Administrative Sanction \\
\hline 18 & $\begin{array}{l}\text { Service Providers for Settlement of Environmental } \\
\text { Dispute }\end{array}$ \\
\hline & \\
\hline
\end{tabular}

\begin{tabular}{|c|l|}
\hline No & \multicolumn{1}{|c|}{ Ministerial Regulations Needed } \\
\hline 1 & $\begin{array}{l}\text { Quality Standard of Environment outside Governement } \\
\text { Regulation }\end{array}$ \\
\hline 2 & Criteria of Activities Subjected to AMDAL \\
\hline 3 & $\begin{array}{l}\text { Criteria and Certificate of Competency in } \\
\text { Preparing AMDAL }\end{array}$ \\
\hline 4 & Licensing Procedures \\
\hline 5 & $\begin{array}{l}\text { UKL-UPL and statement on the capability of } \\
\text { environmental management and monitoring }\end{array}$ \\
\hline 6 & Environmental Audit \\
\hline 7 & Information system on environment \\
\hline 8 & Complain procedures \\
\hline 9 & Environmental losses \\
\hline
\end{tabular}

After more than 10 years of UU PPLH, several downstream regulations mentioned in the table above have been stipulated, while several others have not. Those that have been stipulated include Government Regulation (PP) No. 46/2017 on Instruments of Economic Instruments of the Environment, PP No. 46/2016 on KLHS Procedures, and PP No. 27/2012 on Environmental Permit. At the level of ministry, the regulations include Permen (Ministerial Regulation) No. 17/2010 on Environmental Audit, Permen No. 15/2010 on Requirements and Procedures for AMDAL Evaluation Commission Licensing, and Permen No. 10/2010 on Procedure of Complaint and Complaint Handling for
Environmental Pollution and/or Destruction Allegation. The Ministry of Environment and Forestry have to stipulate other required regulations to enforce UU PPLH. The technical downstream regulations should be based on the green constitution principles in UU PPLH.

\subsection{Environmental Legislation Commitment in Bangka Belitung}

Bangka Belitung Islands Province, a region in Southeast Asian Tin Belt, has been exploited for more than three centuries, resulting in thousands of ex-tin mining holes in the region [13, 14]. The ongoing tin mining left thousands of ex-tin mining holes with little to none reclamation efforts. The increasing number of critical lands has caused numerous problems, including flood in several areas and damaged coral reef in the sea.

This condition calls for an effective strategic policy from provincial and regency/city governments. Pursuant to Law No. 23 of 2014 on Regional Government, the authority for environmental management is mandatory to regional government, but it is not related to basic services. In provincial level, the environmental regulations include:

1. Provincial Regulation No. 8/2018 on Environmental Pollution and Damage Control

2. Provincial Regulation No. 10/2016 on Watershed Management

3. Provincial Regulation No. 7/2012 on Corporate Social and Environment Responsibilities

4. Provincial Regulation No. 4/2009 on Groundwater Management.

Environmental regulations in regency/city of Bangka Belitung Islands include:

1. Pangkalpinang City Regulation No. 2/2014 on Environmental Permit

2. Pangkalpinang City Regulation No. 12/ 2005 on ExTin Mining Holes Management and Utilization

3. Pangkalpinang City Regulation No. 3/2006 on Waste and Sanitation Management in Pangkalpinang City

4. Central Bangka Regency Regulation No. 13/2016 on Management and Control of Waste of Hazardous and Toxic Materials

5. Bangka Regency Regulation No. 9/2015 on Environmental Permit

6. West Bangka Regency Regulation No. 10/2015 on Businesses and/or Activities that are Required to Provide Environmental Documents

7. South Bangka Regency Regulation No. 2/2015 on Domestic Waste Water System

8. Belitung Regency Regulation No. 1/2016 on Environmental Permit

9. East Belitung Regency Regulation No. 7/2016 on Green Open Space Management.

Viewing that the environmental problems in Bangka Belitung are complex, the above environmental regulations are less than adequate. This region requires an effective regulation that encourages preventive measures, while having legal force to rehabilitate lands, rivers, and sea that are damaged by mining. The minimum number 
of environmental regulations is not in line with strategic issues, vision, and missions of the head of the government, whose tagline is to have an environmentally sustainable development.

\section{Conclusion}

Environmental law system has seen its essence in the 1945 Indonesian Constitution, a green constitution whose purpose is to guarantee the people's rights to sound and healthy environment as well as to green national economy. The constitutional norm takes the form of UU PPLH, which becomes the umbrella act for environmental regulations that cover various sectors. The downstream regulations of UU PPLH are enforced as government regulations, ministerial regulations, and other technical regulations. However, this downstream regulation is not yet optimized since some regulations are still unavailable. Some of the downstream regulations in Bangka Belitung Islands reflects the central regulations, but several others are formulated based on the environmental protection need in the respective province or regency/city. Nevertheless, the existing regulations is still inadequate to support preventive measure and enforce rehabilitation/reclamation in increasing number of critical lands.

We thank the General Directorate of Higher Education of Ministry of Education and Culture, Republic of Indonesia for funding this research under the Basic Research Scheme 2020-2022 with 141.A/UN50.11/PP//2020.

\section{References}

1. B.N. Arief. Law Enforcement Issues and Crime Countermeasures Policies, PT Citra Aditya Bakti, pp. 83-86 (2001).

2. S. Sunarso., Environmental Criminal Law and Dispute Settlement Strategies, Rineka Cipta, pp. 2-3 (2005)

3. E.Nurtjahya, et.al. The Impact of tin mining in Bangka Belitung and its reclamation studies, Web Conferences, 101, pp. 1-6 (2016)

4. I. Ibrahim, D. Haryadi, N. Wahyudin. From Charm To Sorrow: The Dark Portrait Of Tin Mining In Bangka Belitung, Indonesia, People: International Journal of Social Sciences, 4 (1), pp. 360-382 (2018)

5. M. Abdurahman. Sociology and Legal Research Methods], UMMPress, pp. 129-130 (2009)

6. PM. Marzuki. Legal Research. Kencana. pp. 96 (2005)

7. J. Asshiddiqie, Green Constitution, RajawaliPress, pp. 90 (2009)

8. The Chair of the People's Consultative Assembly and the Information Dissemination Task Force of the People's Consultative Assembly for the period 20092014, Four Pillars of the Nation and State, Sekretariat Jendral MPR RI. pp. 80 (2012)
9. O. Rosadi. Ecology and Social Justice (In the Perspective of Legal Philosophy), Thafa Media, pp. 199 (2012)

10. Darwance, D. Haryadi. Yokotani. Reconstructing the Development of Eco-Friendly Environment as the Green Constitution (A Study of Tin Mining and Environmental Degradation in Bangka Belitung Island). Atlantispress. 358. pp. 119-122 (2019)

11. Haryadi, Darwance, R. Dwi Salfutra. Integrative Law Enforcement about Tin Mining Reclamation Responsibility at Bangka Belitung Island. Web Conferences, 68, pp. 1-6 (2018)

12. K. Hardjasoemantri, Environmental Law and Governance. Eighth edition, Gadjah Mada University. pp. $76(2005)$

13. S. Sujitno. The Impact of Tin throughout the History in Indonesia. Cempaka Publishing, pp. 7 (2005)

14. J. Susilo dan S. Maemunah. Three Centuries Serving the World (Portrait of Tin Mining in Bangka Belitung Islands). Jatam. pp. 43 (2002) 